\title{
Monetary Policy Shock and Manufacturing Output in Nigeria (1981-2018)
}

\author{
Hammed, Yinka Sabuur \\ Dept. of Economics, Obafemi Awolowo University, P.M.B 13 \\ *Corresponding author email: yinkameds@gmail.com
}

Received: 02 December 2019 / Revised: 26 January 2020 / Accepted: 15 February 2020 / Published: 22 February 2020

\begin{abstract}
This study empirically investigates the impact of monetary policy shock on the manufacturing output in Nigeria using time series data covering the period between 1981 and 2018. Co-integration test was used to establish the long run relationship among the variables and Structural Vector Auto-Regressive model was employed to test for the shocks. It was found that shock to broad money supply would bring about positive and significant impact on the manufacturing output while the impact of shock to interest rate was found to be negative and insignificant. This study however concludes that shock to broad money is the main monetary policy instrument which can bring about positive change to manufacturing output in Nigeria. This paper then suggests that government and policy makers should primarily focus on this variable in their implementation of unanticipated monetary policy.
\end{abstract}

Keywords: Monetary policy, interest rate, money supply, manufacturing output, S-VAR.

\section{Introduction}

The manufacturing sector is widely considered to be the ideal sector to drive Africa's development. This is due to the labour-intensive and export focused nature of the industry. There is no doubt that there exists a direct correlation between exportation levels and the economic success of a country (Obioma and Anyanwu, 2015). By increasingly adding value to products before they are sold, revenues are boosted, thereby raising average earnings per input. They equally argued that the manufacturing sector is also more sustainable and less vulnerable to external shocks. In this regard, the role being played by the manufacturing sector in any economy could never be over-emphasized. In addition to its generation of employment opportunities for the teeming unemployed youths, the sector contributes greatly to the growth of output in the economy. In 2018 alone, the contribution of the sector to the GDP of Nigeria is about 10\% with $24 \%$ growth rate which is almost double when compare with the previous year (CBN, 2019).

The manufacturing output stimulates the economic growth which would eventually translate to increase in country's real output and services. In terms of capacity utilization, the sector makes use of available raw materials and other inputs both locally and internationally at selective cost in order to make meaningful impact on the economy. Resulting from this is the fact that the sector helps to reduce the situation of unemployment in the country. With the establishment of more firms by Nigerians, private sectors, the government and foreigners, more people are being employed. This has invariably led to high standard of living of the people (Obichukwu, 2013). The manufacturing industries in Nigeria so far have done well in the production of goods to the nation. Recent studies have shown that Nigeria goods are being exported to other countries. Nigerians now patronize made - in - Nigeria goods (Obioma and Anyanwu, 2015). The policies of the present Buhari-led administration which is to reduce corruption, ensure security of lives and property and to have a healthy economy are playing a greater role in improving the activities of manufacturing sector in the country. Recently, specifically in 2019, the administration has embarked on the total closure of the land border with neighboring countries like Niger, Benin Republic and others, all to ensure that local production is boosted and security of people and property, which in no doubt has economic implications. Although, such a policy could be blamed on the unavailability of the alternative

Copyright (C) 2020. The Author(s). Published by AIJR Publisher.

This is an open access article under Creative Commons Attribution-NonCommercial 4.0 International (CC BY-NC 4.0) license, which permits any non-commercial use, distribution, adaptation, and reproduction in any medium, as long as the original work is properly cited. 
Monetary Policy Shock and Manufacturing Output in Nigeria (1981-2018)

measures, its positive impact is gradually being felt in the country. Nigerians are now consuming made in Nigeria rice and other consumable items. This is really great for the country, and it is expected that in any moment soon, the impact would be manifested in all sectors of the economy.

According to Ogundipe et al (2017), monetary policy as one of macroeconomic tools could be used to stimulate economics towards the achievement of macroeconomic goals such as price stability, exchange rate stability, maintenance of equilibrium balance of payment, employment generation, and promotion of output and sustainability growth. In connection to this, the federal government of Nigeria under the Buhariled administration has equally targeted some sectors in its bid to develop the country, of which manufacturing sector is included. In this connection, it becomes pertinent to know what exact effect a sudden change in interest rate or money supply would have on the activities of manufacturing sector. It is generally believed that the level of investment would rise in response to a low rate of interest. Also, with the notion of Savers-Spenders theory, an increase in money supply would result into an increase in the level of savings and consumption. Thus, it becomes apparent that shocks to monetary policy (positive shock) would tend to improve the activities of manufacturing sectors. The result would entirely be different, if the shock is negative.

As a way of contributing to the literature, this study seeks to examine the impact of monetary policy on the activities of manufacturing sector and to equally find out the effect of shock to manufacturing output on the aggregate output of the economy using structural vector autoregressive approach with data spanning from 1981 to 2018. It is believed that any innovation to manufacturing output would be most significant to aggregate output. In achieving this objective, this paper is structured into six sections, namely: introduction, trend analysis of manufacturing sector, the review of related literature, the methodology, discussion of findings and the conclusion.

\subsection{Trend Analysis of Manufacturing Sector in Nigeria}

This analysis, as shown in figure 1, is presented in three periods. Period one covers 1981 to 1990, period two, 1991 to 2000 and period three, 2001 and 2018. During the first decade, the period between 1981 and 1990 , the manufacturing output was a bit steady, though with extremely low values. The average growth rate for the period was $14.7 \%$ and average share of the sector to total GDP was $18.2 \%$.

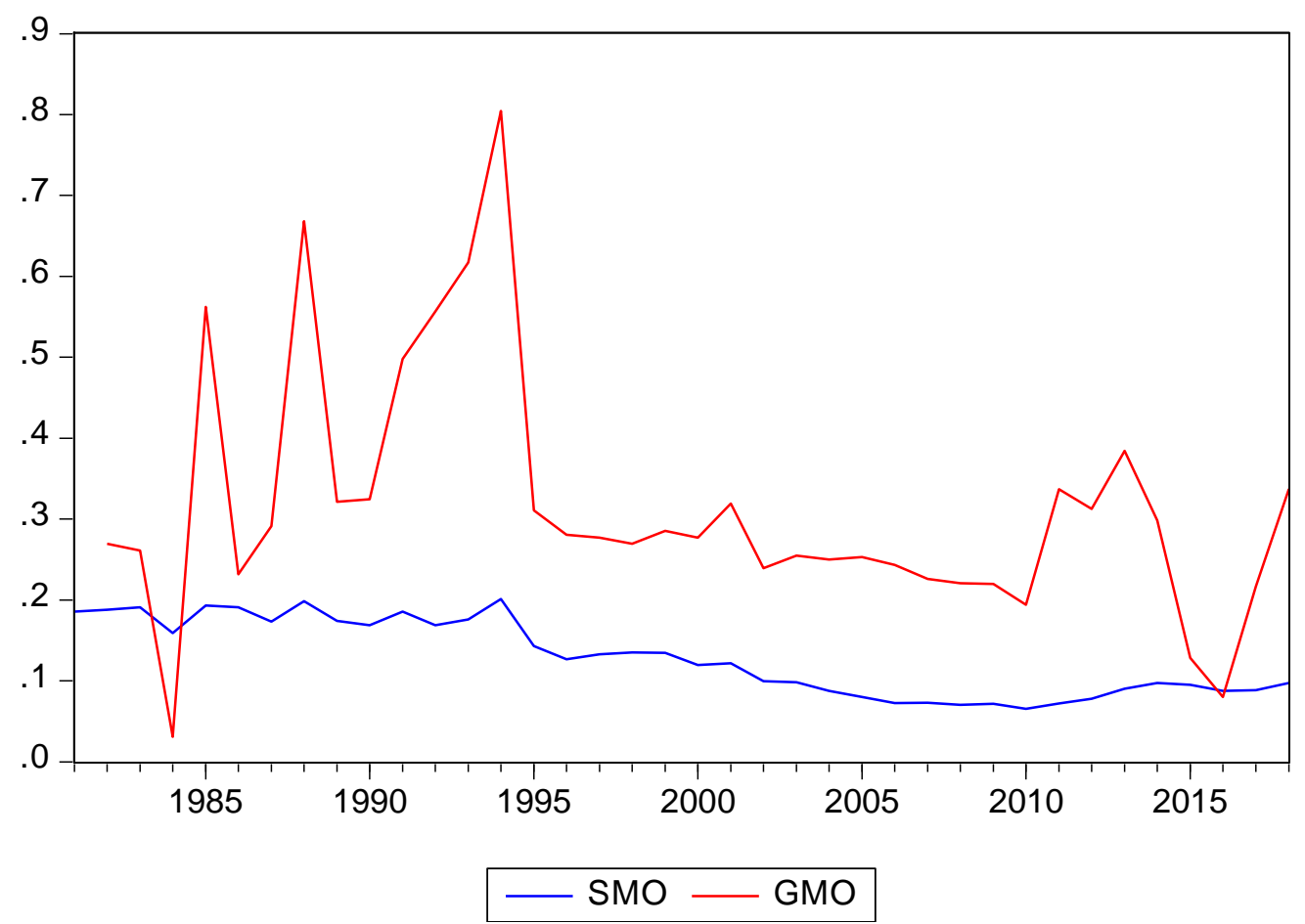

Figure 1: Showing the trend analysis of Manufacturing Sector in Nigeria between 1980 and $2018(C B N, 2019)$ 
Yinka Sabuur Hammed, Adv. J Social Sci.; Vol. 7, Issue 1, pp: 27-37, 2020

The performance of the sector was quite low in the year 1984 when the output from the sector fell by $12.9 \%$ and the contribution to the GDP was $15.9 \%$. However, the highest growth was achieved in 1990 with a rate of $15.5 \%$ and the output was $\$ 84.3$ billion. At this period, the contribution of the sector to GDP was $16.9 \%$, well below the average share for the decade. This could be attributed to the collapse of the world oil market from the early 1980s, which drastically reduced foreign exchange earning capacity needed to enable the sub-sector import inputs for production process. The negative growth rate for 1984 could also be attributed to the forceful change in power from civilian to military government which could suggest a strange environment for the stakeholders in the sector couple with the aftermaths of various reactions from the citizens.

The early part of the periods 1991 to 2000 could be better described as 'magical periods' for the manufacturing sector as it enjoys positive growth rates all through. The average growth rate was almost $27 \%$ (about 12\% higher than the figure for the first decade) while the average manufacturing output was $\$ 443.9$ billion (about $890 \%$ rise when compared with average value of the first decade). The beginning of the decade was very fantastic for the manufacturing sector with a positive growth rate of $31.2 \%$. This is followed by $38.8 \%, 44.2 \%$ and $60.3 \%$ growth rates respectively for the subsequent years. In terms of value, the sector recorded highest production value of 826.03 billion in the year 2000 with growth rate of $15.7 \%$. The sector's share in the GDP was equally high in the periods between 1991 and 1995. The highest share was in the year 1994 with a rate of $20.1 \%$ followed by $18.6 \%$ in 1991 . The sub sector's contribution to GDP was quite low in the subsequent years starting from 1996 to 2000 . The least rate of $12 \%$ was recorded in the year 2000. The significant growth rates in the sector's output as well as the high contribution rate to the GDP could be attributed to the aftermath of the positive impact of Structural Adjustment Programme. The subsequent fall in the rates could be premised on the fading out of the programme which made it to have minimal effect on the manufacturing sector. It could further be attributed to various political unrests that were very rampant around these periods.

The periods between 2001 and 2018 equally saw the manufacturing sector recording unimpressive performance in terms of growth rate and contribution to GDP. The average growth rate for these periods was $16.5 \%$ (about 10\% lower in rates than the previous decade) while the average value of production level was 4 ,840.1 billion far higher than the figure for the previous decade (about $990.4 \%$ increase). However, on the growth rate, one special thing about it is its being steady with little variance. The highest growth recorded was in the year 2013 with about $29.4 \%$ which could be a fall out of pre-election spending for election activities while the lowest was in the year 2016 with a fall of $0.8 \%$. In terms of value, the production value for the year 2018 was the highest with a value of $\$ 12,455.5$ billion while the lowest was in the year 2001 which has a value of 989.11 billion. The performance of the sector in the years 2005, 2006, 2011, 2014 and 2018 was highly remarkable with growth rates of $17.3 \%, 17.1 \%, 26.5 \%, 20.1 \%$ and $24 \%$ respectively. In the area of contribution to GDP, the average share of manufacturing sector in country's GDP for whole period stands at 8.6\% lower than the previous decade. Right from year 2000 the share had been on decrease up to year 2013. However, there was a slight increase in the year 2013, 2014 and a very slight fall in 2015 with the contribution rates of $9.0 \%, 9.8 \%$ and $9.5 \%$. This could be blame on the government attitude in the provision of energy and other key infrastructural facilities needed for any meaningful transformation in the sector. The little fund made available for this purpose was not utilized for the intended purpose.

The growth rate of the sector for the year 2018 has been very appreciating with $24 \%$ which is far higher than $12.8 \%$ and a fall of $0.8 \%$ in 2017 and 2016 respectively. In term of the contribution to the GDP, the sector contributes a total of $9.7 \%$ to the economy in 2018; a greater improvement from $8.8 \%$ of two previous year. It could be said that the effort of the present Buhari-led administration to have a healthy economy is gradually making positive impact in economy. 
Monetary Policy Shock and Manufacturing Output in Nigeria (1981-2018)

\section{$1.2 \quad$ Literature Review}

Several researches have been done on how monetary policy impacts the economy. Many of the researchers in this area looked into the relationship between monetary policy and manufacturing output, with few of them analysing the impact of shocks alongside their works. Many of the studies on the impact of monetary policy on manufacturing output agree that money supply (broad) shock, interest rate shock, bank lending and capacity utilization affect manufacturing output.

Monsor and Razita (2005) examined the dynamic responses of manufacturing output to exchange rate and monetary policy shocks in Malaysia. Their findings were in supportive of the contention that shocks in the interest rate and exchange rates have significant effects on manufacturing output in magnitudes greater than their influences on aggregate output or output of other sectors. The study by Alam and Waheed (2006) examined the channels of monetary transmission in Pakistan across seven sectors (agriculture, mining and quarrying, manufacturing, construction, wholesale and retail trade, finance and insurance, and ownership of dwellings) of the economy. The finding of the study revealed that manufacturing, wholesale and retail trade, and finance and insurance sectors declined more in response to the interest rate shocks while the agriculture, mining and quarrying, construction, and ownership of dwellings were observed to be insensitive to interest rate changes. The work of Vizek (2006) centred on the analyses of monetary transmission in Croatia using the Granger causality test and error correction model. The author concludes that monetary policy affects industrial output through changes in the exchange rate and money supply, while interest rate changes do not have any influence.

Saygin and Evren (2010) as quoted in Imoughele and Ismaila (2014) evaluated sectorial growth cycles and the impact of monetary policy in the Turkish manufacturing industry. The main objective of the study is to investigate the response of output in Turkish manufacturing industries to monetary policy shocks. According to the VAR results, all manufacturing sectors respond to a tightening monetary policy shock with a reduction in absolute output. The total manufacturing output declines very quickly after the shock, reaching its minimum value within three quarters. The degree of this output reduction, however, is not the same for all manufacturing sectors. Some of the sectors are more severely affected whereas others are not deeply affected at all and concluded that a contraction monetary policy shock has a limited effect on Turkish manufacturing industries. Obamuyi, Edun and Kayode (2010) examined the effect of bank lending and economic growth on the manufacturing output in Nigeria. The study employed the unit root, co-integration and vector error correction model (VECM) on a time-series data from 1973 to 2009. The findings of the study show that manufacturing capacity utilization and bank lending rates significantly affect manufacturing output in Nigeria. However, the relationship between manufacturing output and economic growth could not be established in the country.

Charles-Anyaogu (2012) wrote on the performance of monetary policy on manufacturing sector in Nigeria using time series data that spans from 1980 to 2009. The methodology adopted was Vector Error Correction model with OLS estimation. His findings revealed that manufacturing output was influenced by money supply while other variables, as used in the study, were negatively related to output of manufacturing sector. Odior (2013) empirically investigated the impact of macroeconomic factors on manufacturing productivity in Nigeria over the period 1975 to 2011. The analysis starts with examining stochastic characteristics of each time series by testing their stationarity using Augmented Dickey Fuller (ADF) test and estimate error correction mechanism model. The findings were reinforced by the presence of a longterm equilibrium relationship, as evidenced by the co-integrating equation of the VECM. The study showed that credit to the manufacturing sector in the form of loans and advances and foreign direct investment have the capacity to sharply increase the level of manufacturing productivity in Nigeria, while broad money supply has less impact. He concluded that expansionary policies were vital for the growth of the manufacturing sector in Nigeria which in turn would lead to economic growth.

Nneka (2012) examined the performance of monetary policy on manufacturing sector in Nigeria for time frame 1986 to 2009. Vector Error Correction (VEC) and Ordinary Least Square (OLS) estimation were 
Yinka Sabuur Hammed, Adv. J Social Sci.; Vol. 7, Issue 1, pp: 27-37, 2020

used to study the models for significance, magnitude, direction and relationship. The study revealed that money supply positively affected manufacturing output index while company lending rate, company income tax rate, inflation rate, and exchange rate had a negative impact to the performance of the manufacturing sector over the years. Owolabi and Adegbite (2014) examined the impact of monetary of monetary policy on industrial growth in Nigeria using time series data from 1980 to 2011. The research method was simple OLS and the finding revealed that rediscount rate and deposit significantly affected industrial output. Chigbu and Okonkwo (2014) in their work "monetary policy and Nigeria's quest for import substitution industrialization" using the error correction mechanism came to the conclusion that money supply exacted tremendous pressure on industrial output in Nigeria, thus, collaborating the monetarists preposition which suggests that money supply is directly proportionate to real output. The work of Imoughele and Ismaila (2014) focused on the impact of monetary policy on manufacturing sector performance in Nigeria using time series data from 1986 to 2012. They adopted VAR analysis and their findings revealed that growth in manufacturing sector is highly responsive to exchange rate, external reserve and inflation. The study equally found a long run relationship between manufacturing sector output and monetary policy variables. Osmond, Egbulonu and Emerenini (2015) investigated the impact of monetary policy on manufacturing sector in Nigeria using error correction model. The data for the study was time series from 1981 to 2012. The study revealed that money supply and credit to private sector exerted tremendous pressure on the manufacturing sector. The study of Ogundipe at al. (2017) examines the effect of monetary policy using four monetary transmission mechanism channels and included a fiscal policy variable. The result shows that the lending rate accounted for the biggest variance in the manufacturing contribution to the gross domestic product, given the forecast error decomposition. The study then recommended that the lending interest rate to the manufacturing sector should be within the single digit.

\section{Theoretical Framework: St. Louis Equation}

The St. Louis Equation was developed in 1968 in an article in this Review by Leonall Anderson and Jerry Jordan. The equation is an estimated relationship between changes in total spending (GNP) and changes in money supply and high-employment federal expenditures. The focus of the Anderson-Jordan equation was on the relative impact of monetary and fiscal actions. They rejected the propositions that the response of economic activity to fiscal actions relative to monetary action was larger, more predictive and faster. In fact, the theory (the result from the empirical analysis using the equation) suggests that the overall effect of fiscal actions was relatively small and not statistically significant. It was this result that generated considerable controversy among members of the economic profession. The conventional wisdom of the time was that fiscal action (whether in the form of a maintained increase in expenditure or a tax cut) did have an impact on economic activity, with a multiplier estimated at about 1.5 or greater.

In a recent article, Benjamin Friedman published updated estimates of the St. Louis equation. According to Friedman, the St. Louis equation now believes in fiscal policy. He presented results showing that St. Louis equation yield a significant government spending multiplier of about 1.5. This conforms to the neoKeynesian thinking. At the same time, Friedman duly noted that with these updated estimates, the relative strong impact of monetary actions continues to hold.

\section{Research Methodology}

\subsection{Model Specification}

The broad objective of this study is basically to examine the impact of monetary policy shocks on the manufacturing output in Nigeria. In order to realize this objective, an econometric investigation procedure is adopted to understand the behaviour of time series data which allows the development of suitable model. The operationalization and analytical procedure are based on the St. Louis Equation Theory. The St. Louis equation model is estimated in the following form-

$$
\Delta Y=\alpha+\sum \beta_{i} \Delta M_{t-1}+\sum \gamma_{i} \Delta G_{t-1}+U_{t}
$$


Monetary Policy Shock and Manufacturing Output in Nigeria (1981-2018)

Where the endogenous variable Y denotes nominal GNP and the money stock and high-employment government expenditure, being the exogenous variables, are denoted by $\mathrm{M}$ and $\mathrm{G}$ respectively. The usual random error is represented by $U_{t}$. In line with this theoretical framework, the Equation (1) relates economy's output (GNP) to money stock (monetary policy indicator) and government expenditure. However, for proper estimation of the impact of monetary policy shocks on the sectoral output, the level of economy's output could be limited to that of manufacturing sector. Therefore, the model to establish the impact of monetary policy shocks on manufacturing sector in Nigeria could be stated as follows.

The specification is expressed in functional form as:

$M O=f(M P)$

Where MO is manufacturing sector output used as proxy for growth in manufacturing sub-sector and MP is monetary policy. As suggested by the theoretical framework, variables of monetary policy are basically money supply and interest rate. On this basis, using necessary variables for the policy, equation (2) could be re-specified as follows:

$M O=\phi_{0}+\phi_{1} M_{2}+\phi_{2} I R+\xi$

From equation (3) above, $\mathrm{MO}$ is the Manufacturing Output, $\mathrm{M}_{2}$ stands for broad money supply, and IR, for interest rate. The $\phi$ 's are the parameters of the model. However, given the large magnitude of the values of the variables used, log-log mode is applied. Without this, it might be somewhat difficult to achieve the stationarity property of the data which is an essential ingredient for any econometric analysis. This would then serve as a way of indexing all the variables and also aid the interpretation of the result. Therefore, equation (3) becomes:

$$
\log M O=\phi_{0}+\phi_{1} \log M_{2}+\phi_{2} I R+\xi
$$

In order to examine the relationship among shocks to broad money supply, interest rate and manufacturing output, Vector Auto-regressive method is used for the estimation. This technique captured the shocks to monetary policy as it affects manufacturing output. It also captured both the short and long-run dynamic relationship. The choice of this technique rests on the fact that it is a convenient device for summarizing the first and second moment properties of the data which make VAR analysis easy to carry out. However, from equations (4), the VAR model could be stated in matrix form as follows:

$$
\left(\begin{array}{l}
M O_{t} \\
M 2_{t} \\
I R_{t}
\end{array}\right)=\left(\begin{array}{l}
\phi_{10} \\
\phi_{20} \\
\phi_{30}
\end{array}\right)+\sum_{i=1}^{j}\left(\begin{array}{ll}
\phi_{1 t} & \varphi_{1 t} \\
\phi_{2 t} & \varphi_{2 t} \\
\phi_{3 t} & \varphi_{2 t}
\end{array}\right)\left(\begin{array}{l}
M O_{t-1} \\
M 2_{t-1} \\
I R_{t-1}
\end{array}\right)+\left(\begin{array}{l}
\xi_{1 t} \\
\xi_{2 t} \\
\xi_{3 t}
\end{array}\right)
$$

Equations (5) could also be presented in simple forms as follows:

$$
Z_{t}=b+\sum_{i=1}^{k} n_{i} Z_{t-i}+\varepsilon_{1 t}
$$

From equation (6) $Z_{t}$ is a $\mathbf{k x 1}$-dimensional vector of the endogenous variable for model one, $b$ is a $\mathbf{k x 1}$ dimensional vector of constant and $n_{i-k}$ are kxk-dimensional autoregressive co-efficient matrices of parameters of lagged value of variables of $Z_{t}$ and $\varepsilon_{1 t}$ is the $\mathrm{kx} 1$-dimensional vector of the stochastic error term normally distributed with white noise properties $N\left(0, \sigma^{2}\right)$. In this case, it is regarded as shock or innovation to each of the variables use in this study. 
Yinka Sabuur Hammed, Adv. J Social Sci.; Vol. 7, Issue 1, pp: 27-37, 2020

\subsection{Source of Data}

This study made use of secondary data. Data on manufacturing output and broad money supply, M2 was sourced from Central Bank of Nigeria (CBN) bulletin while data for interest rate was sourced from World Development Indicator (WDI) bulletin.

\subsection{Unit Root Test}

Time series variable must be stationary so that its behaviours could be studied over time and accurate predictions could be made in that regard. Thus, it essential to check the properties of time series data before analyzing the relationship that exists among them. However, it is always pertinent to carry out unit root test on all the variables of interest in order to know their properties and put appropriate measure in place to correct them where necessary. This is exactly what we have examined in this section. The order of the series for the stationarity of the data was checked through two different unit root tests that are mostly common in the literature. Namely: Augmented Dickey-Fuller (ADF) and Phillip-Perron (PP). Table 1 shows that $\operatorname{lmo}, \operatorname{lm} 2$, er and ir are all I(1) for both the ADF and PP when the unit roots with individual intercept and trend were considered.

Table 1: Unit Root Test (ADF)

\begin{tabular}{|l|l|l|l|l|l|l|l|}
\hline & Intercept & & & Intercept & \multicolumn{2}{l|}{ and Trend } & \multicolumn{2}{l|}{} \\
\hline Variable & Level & 1st Difference & Remark & Level & \multicolumn{1}{l|}{ 1st Difference } & Remark \\
\hline Imo & -0.6225 & -4.5821 & $\mathrm{I}(1)$ & -0.6981 & -4.5472 & $\mathrm{I}(1)$ \\
& $(0.8531)$ & $(0.008)$ & & $(0.7314)$ & $(0.0046)$ & \\
\hline $\operatorname{lm} 2$ & -0.7559 & -3.6629 & $\mathrm{I}(1)$ & -0.4886 & -3.7129 & $\mathrm{I}(1)$ \\
& $(0.8197)$ & $(0.0091)$ & & $(0.9797)$ & $(0.0342)$ & \\
\hline er & -1.7283 & -4.2168 & $\mathrm{I}(1)$ & -1.9458 & -4.5483 & $\mathrm{I}(1)$ \\
& $(0.9995)$ & $(0.0021)$ & & $(0.6101)$ & $(0.0045)$ & \\
\hline ir & -2.4413 & -2.8406 & $\mathrm{I}(1)$ & -1.0687 & -6.1981 & $\mathrm{I}(1)$ \\
& $(0.1383)$ & $(0.0647)$ & & $(0.0041)$ & $(0.0001)$ & \\
\hline
\end{tabular}

\subsection{Co-integration Test for all the Variables}

The co-integration test was carried out for this study in order to ascertain the log run relationships that exist among the variables as used in this study. The co-integration employed was that of Johansen (1998). The result presented in table 2 shows the summary of the unrestricted co-integration rank test (Trace and maximum eigen value). The result revealed one (1) co-integration equations at $5 \%$ level of significance for the model. This, however, implies that there is co-integration among the variables and by implication suggests the use of Structural Vector Error Correction Model, SVECM for our analysis. However, this would go beyond the scope of this paper mainly due to non-implementation of the menu to process the analysis in the available choice of software. Nevertheless, Blanchard and Perotti (2002) find no significant difference in results when imposing the co-integration relationship among the variables (i.e. the result obtained from the use of SVECM and SVAR). This, however, gives us more confidence that implementation of our analysis through SVAR would give adequate result just as SVECM. Thus, the SVAR was employed for this study. The determination of the shocks to each of the endogenous variables, in this regard, was therefore done via impulse response from the SVAR.

Table 2: Co-integration Test for all Variables

\begin{tabular}{|l|l|l|l|l|}
\hline & Trace & & Maximum-Eigen Value & \\
\hline & Trace Statistic & Probability & Max-Eigen Statistic & Probability \\
\hline None & & & & \\
\hline At most 1 & 66.75 & $0.0003^{* * *}$ & 37.94 & $0.0017^{* * *}$ \\
\hline & 28.82 & $0.0646^{*}$ & 18.05 & 0.1281 \\
\hline
\end{tabular}


Monetary Policy Shock and Manufacturing Output in Nigeria (1981-2018)

\begin{tabular}{|l|l|l|l|l|}
\hline At most 2 & 10.77 & 0.2262 & 6.920 & 0.4986 \\
At most 3 & 3.847 & 0.0498 & 3.846 & 0.0498 \\
\hline \multicolumn{4}{|c|}{ Note: ***,**, and * denote 1\%,5\% and 10\% levels of significance respectively } \\
\hline
\end{tabular}

Both trace and Max-Eigen tests indicate 1 co-integration equation at $5 \%$ level of significance

\section{Empirical Findings: Monetary Policy Shock and Manufacturing Output}

The impulse and response functions presented in Table 3 for accumulated and non-accumulated responses show both the point estimate and 95\% bootstrapped confidence intervals based on 5000 replications as suggested by the E-view package. The confidence interval is large enough as it only suggests a $5 \%$ chance of making errors. Thus, we presented the impulse response for 10 periods ahead of time of shocks.

Figure 2 shows the result of our model. The responses of manufacturing to a $1 \%$ shock in broad money supply and interest rate are presented. According to the figure, a $1 \%$ shock to broad money supply raises manufacturing by $0.027 \%$ in period of the shock, which is the highest point it reaches. Therefore, the impact multiplier is smaller than one. The reaction of manufacturing output remains positive in the period one to ten periods and becomes very low in the tenth period with least impact of $0.003 \%$. Figure 3(i) shows the cumulative responses of manufacturing output to a $1 \%$ broad money shock. This presents the total increase of manufacturing output in certain time period due to a shock in monetary variable. The cumulative response of manufacturing output to a shock in money supply is positive throughout the showed periods, though not significant. The economic implication of this is that a sudden increase in the amount of broad money supply would have greater impact on the economy via manufacturing sector at initial period and such an impact would subsequently decrease and at the end dies out.

Table 3: Response of Manufacturing Output to Monetary Policy Shock in Nigeria

\begin{tabular}{|c|c|c|c|c|c|c|c|c|}
\hline \multirow[b]{2}{*}{ PERIOD } & \multicolumn{4}{|c|}{ NON-ACCUMULATED RESPONSES } & \multicolumn{4}{|c|}{ ACCUMULATED RESPONSES } \\
\hline & M2 & $\begin{array}{l}\text { P- } \\
\text { VALUE }\end{array}$ & INTR & $\begin{array}{l}\text { P- } \\
\text { VALUE }\end{array}$ & M2 & $\begin{array}{l}\text { P- } \\
\text { VALUE }\end{array}$ & INTR & $\begin{array}{l}\text { P- } \\
\text { VALUE }\end{array}$ \\
\hline 1 & 0.027434 & 0.01745 & -0.001753 & 0.01712 & 0.027434 & 0.01745 & -0.001753 & 0.01712 \\
\hline 2 & 0.008416 & 0.01856 & 0.031579 & 0.01341 & 0.03585 & 0.02508 & 0.029826 & 0.02115 \\
\hline 3 & 0.016175 & 0.0091 & 0.018508 & 0.00808 & 0.052025 & 0.03004 & 0.048334 & 0.02519 \\
\hline 4 & 0.013468 & 0.00805 & 0.014813 & 0.00724 & 0.065493 & 0.03527 & 0.063147 & 0.03021 \\
\hline 5 & 0.010978 & 0.00719 & 0.011479 & 0.0068 & 0.076471 & 0.04021 & 0.074626 & 0.03523 \\
\hline 6 & 0.008701 & 0.00641 & 0.009012 & 0.00634 & 0.085172 & 0.04486 & 0.083638 & 0.04014 \\
\hline 7 & 0.006861 & 0.00569 & 0.007077 & 0.00581 & 0.092033 & 0.04912 & 0.090715 & 0.04479 \\
\hline 8 & 0.005398 & 0.00504 & 0.005562 & 0.00525 & 0.097431 & 0.05295 & 0.096277 & 0.04907 \\
\hline 9 & 0.004245 & 0.00443 & 0.004372 & 0.00468 & 0.101676 & 0.05635 & 0.100649 & 0.05295 \\
\hline 10 & 0.003337 & 0.00387 & 0.003437 & 0.00412 & 0.105013 & 0.05933 & 0.104086 & 0.05639 \\
\hline
\end{tabular}

As regard the Interest Rate (IR), it can be seen from figure 3(ii) that a 1\% shock decreases manufacturing output at a time of a shock by $0.002 \%$, which is also the lowest point it reaches. However, the effect of the shock for other periods ranges from $0.032 \%$ in the second period to $-0.003 \%$ in the tenth period. The impact of the shock was insignificant in the first period but turns positive and significant in the second period through the fourth period and remains positive (but insignificant) till the end of the tenth period. As regard the cumulative response of the manufacturing output to the shock in IR, it is zero in the first period and becomes positive and insignificant in the second period and through to the last period as shown in figure 3(ii). What the forgoing suggests is that an unanticipated rise in the level of interest rate would result to decrease in the level of manufacturing output at the point of the rise and the would begin to die out as the periods increase. On the other hand, a sudden fall in the rate of interest would bring about an increase in output level at initial stage before it begins to fall in the subsequent periods. This goes in line with the submission of Monsor and Razita (2005) and Alan and Waheed (2006). They came to a conclusion that shock to interest rate (one of the variables of monetary policy) do have a significant impact on the level 
Yinka Sabuur Hammed, Adv. J Social Sci.; Vol. 7, Issue 1, pp: 27-37, 2020

of manufacturing output. the work of Alan and Waheed (2006) specifically argued that manufacturing sector of the economy declines more in response to the interest rate shocks. In fact, the work of Saygin and Evren (2010) was equally of this conclusion. They argue that manufacturing output decline very quickly after the shock, reaching its minimum value within three periods. All these submissions are in line the result of this finding in this aspect.

Response to Cholesky One S.D. Innovations \pm 2 S.E.

Response of MO to M2

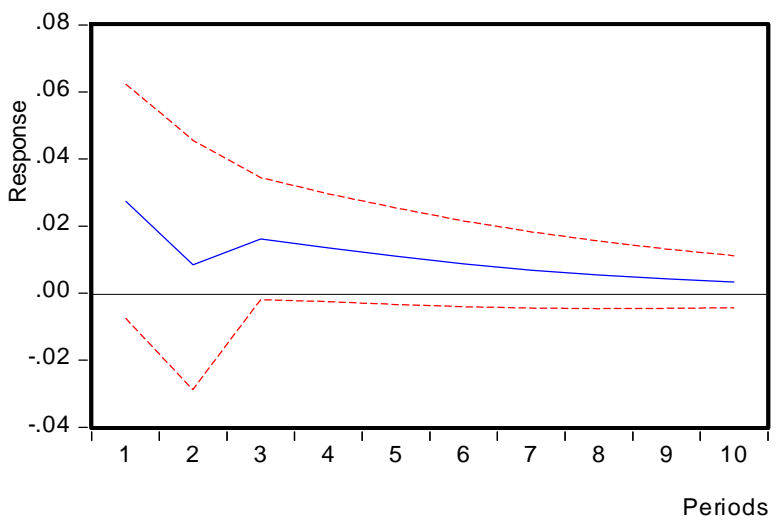

Figure 2(i): showing response of Manufacturing Output to Money Supply
Response of MO to INTR

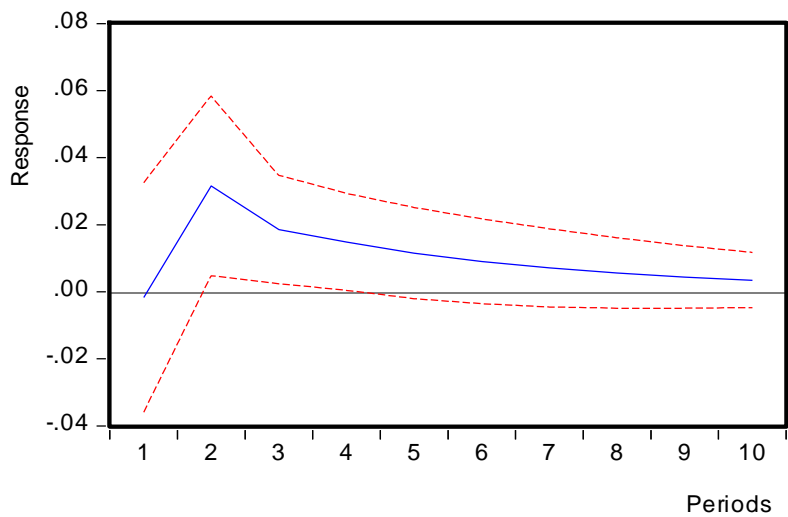

Figure 2(ii): showing response of Manufacturing Output to Interest Rate in Nigeria.

Accumulated Response to Cholesky One S.D. Innovations \pm 2 S.E.

Accumulated Response of MO to M2

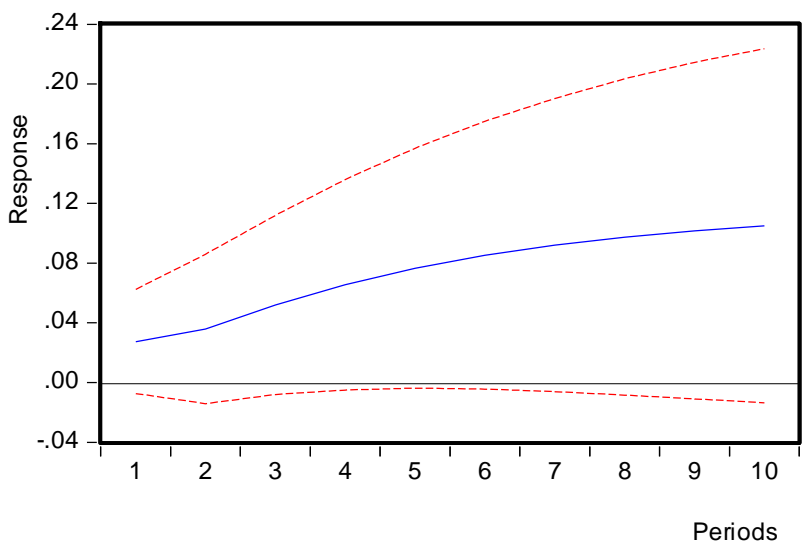

Figure 3(i): showing accumulated response of Manufacturing Output to Money Supply
Accumulated Response of MO to INTR

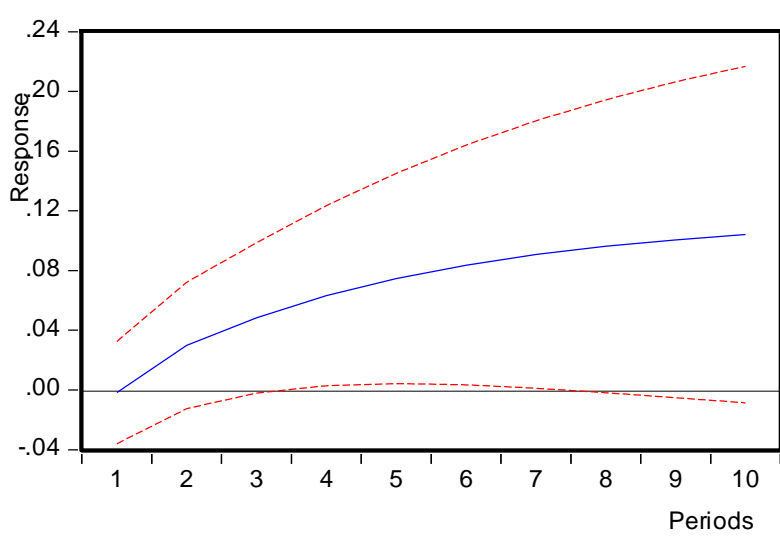

Figure 3(ii): showing response of Manufacturing Output to Interest Rate in Nigeria

\section{$5 \quad$ Manufacturing Sector and Output Growth}

The result in table 4 and figures 4(i) and 4(ii) shows show the response of aggregate output to a shock in manufacturing sector. The response was significance and positive all through. What this informs is that any innovation in manufacturing sector of the economy would exact a greater impact on the aggregate output. At the first quarter, a $1 \%$ shock to manufacturing output leads to a $0.003 \%$ innovation in aggregate output. It fell a bit at the second quarter and later rises up to the last quarter, even though at an increasing rate. This really conforms to the theory. 
Monetary Policy Shock and Manufacturing Output in Nigeria (1981-2018)

Table 4: Response of Manufacturing Output to Monetary Policy Shock in Nigeria

\begin{tabular}{|r|r|r|r|r|r|}
\hline & \multicolumn{2}{|l|}{ NON-ACCUMULATED RESPONSE } & \multicolumn{2}{l|}{ ACCUMULATED RESPONSE } \\
\hline PERIOD & GDP & P-VALUE & M2 & P-VALUE \\
\hline 1 & 0.002781 & 0.00112 & 0.002781 & 0.00112 \\
\hline 2 & 0.002305 & 0.00146 & 0.005146 & 0.00231 \\
\hline 3 & 0.003335 & 0.00143 & 0.008470 & 0.00380 \\
\hline 4 & 0.003666 & 0.00184 & 0.012136 & 0.00473 \\
\hline 5 & 0.003507 & 0.00159 & 0.015638 & 0.00602 \\
\hline 6 & 0.003103 & 0.00155 & 0.018741 & 0.00731 \\
\hline 7 & 0.002652 & 0.00147 & 0.021393 & 0.00854 \\
\hline 8 & 0.002239 & 0.00137 & 0.023632 & 0.00971 \\
\hline 9 & 0.001899 & 0.00129 & 0.025531 & 0.01079 \\
\hline 10 & 0.001636 & 0.00121 & 0.027167 & 0.01180 \\
\hline & & & & \\
\hline
\end{tabular}

Response of OUTP to Cholesky One S.D. MOT Innovation

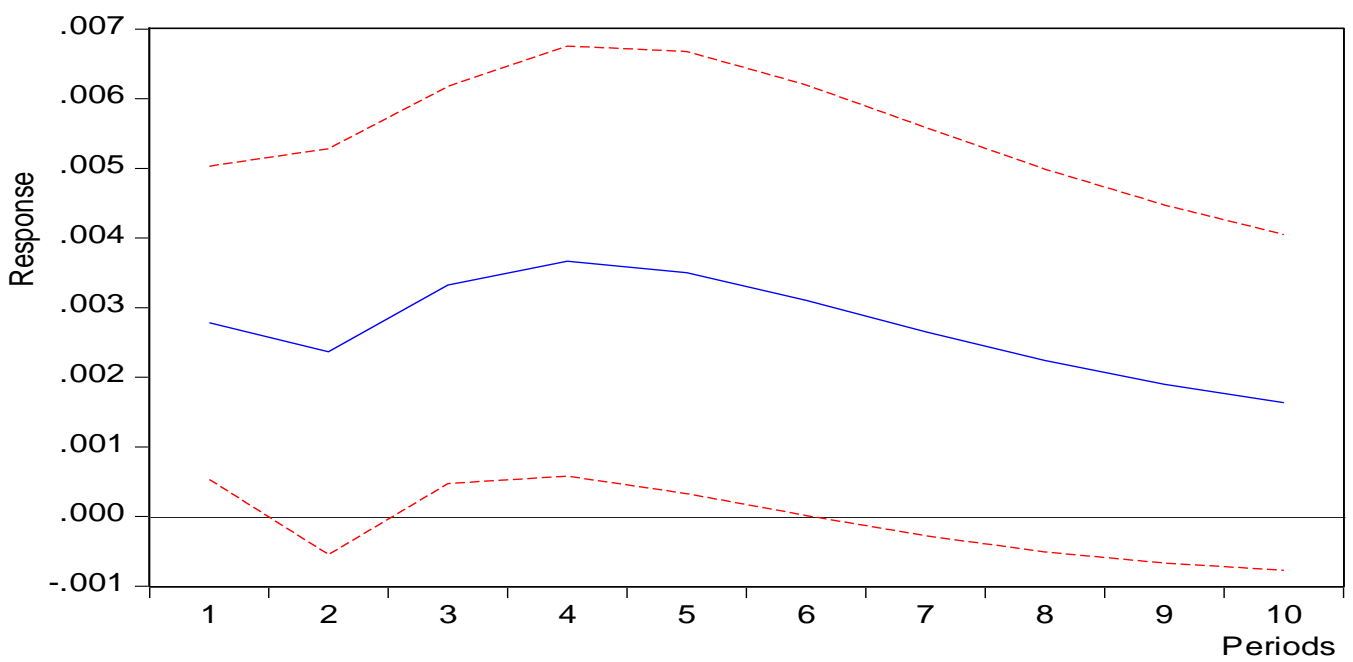

Figure 4(i): Response of Gross Output to a Shock in Manufacturing Sector

\section{Accumulated Response of OUTP to Cholesky} One S.D. MOT Innovation

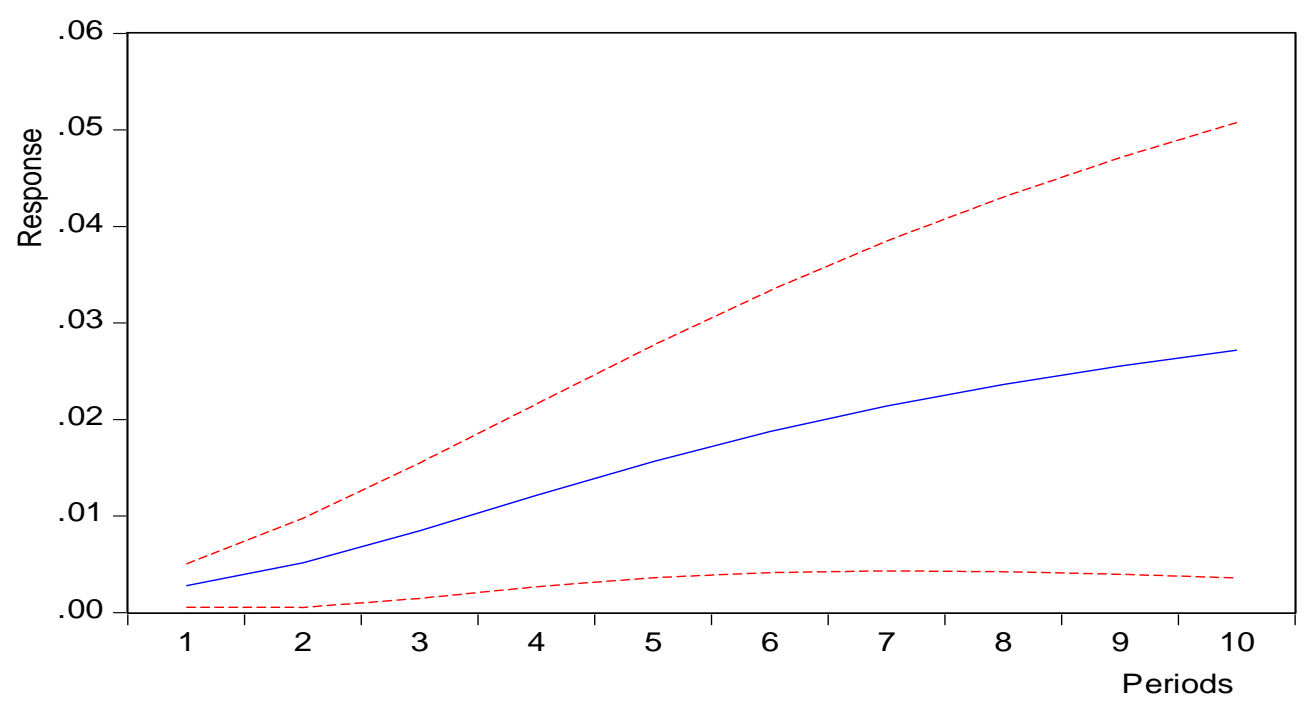

Figure 4(ii): Accumulated Response of Gross Output to a Shock in Manufacturing Sector 


\section{Conclusion}

This study examines the impact of monetary policy shock on the output of manufacturing sector in Nigeria. Based on the findings of the study, it was observed that shocks to monetary policy have positive impact on the manufacturing output. According to this finding, a shock to money supply would lead to a positive change in manufacturing output with significant magnitudes. Also, a negative (i.e. a sudden fall) in interest rate would bring about a positive rise in the output of manufacturing sector at a lower rate when compared with the impact of money supply. In this regard, government should embrace unanticipated monetary policy (i.e. a surprise policy). This would always lead to a positive change in manufacturing output. However, in doing this, much preponderance should be given to money supply as a policy instrument over interest rate, since it has much impact on the economy via manufacturing sector than the interest rate.

\section{Competing Interests}

There is no any known conflict of interest for this manuscript.

\section{How to Cite this Article:}

Hammed, Y. S. (2020). Monetary Policy Shocks and Manufacturing Output in Nigeria (1981-2018). Advanced Journal of Social Science, 7(1), 27-37. doi: 10.21467/ajss.7.1.27-37

\section{References}

Adefeso, H. and Mobolaji, H. (2010). 'The fiscal- monetary policy and economic growth in Nigeria: further empirical evidence.' Pakistan Journal of Social Sciences, 7(2): 137-142.

Alam, T., and Waheed, M. (2006). 'The Monetary Transmission in Pakistan. A Sectorial Analysis: Pakistan Institute of Development Economics.' Munich Personal Re PEc Archive (MPRA) No. 2719.

Chigbu E. E \& Okonkwo O.N (2014). 'Monetary Policy and Nigeria's Quest for Import Substitution Industrialization.' Journal of Economics and Sustainable Development. 5(23), 2014, 99-105.

Imoughele, L.E. and Ismaila, M. (2014). 'Emperical Investigation of the Impact of Monetary Policy on Manufacturing Sector Performance in Nigeria.' International Journal of Education and Research, Vol. 2, NO. 1, January 2014.

Monsor, H.I and Razita, M.A (2005). 'Exchange rate, monetary policy and manufacturing output in Malaysia'. Journal of economic cooperation 26,3. 2005.

Nneka, C.A. (2012). Investigating the Performance of Monetary Policy on Manufacturing Sector in Nigeria: 1980-2009.Arabian Journal of Business and Management Review (OMAN Chapter), 2(1):12-25.

Obamuyi, T.M, Edun, A.T and Kayode, O.F. (2010). 'Bank lending, Economic Growth and The Performance of the Manufacturing Sector In Nigeria'. European Scientific Journal, 8 (3): 19- 36.

Obioma B.K and Anyanwu U.N (2015) 'The effect of Industrial Development on Economic Growth: An Empirical Evidence in Nigeria' European Journal of Business and Social Sciences, Vol 4, No 2, May, 2015.

Odior, E.S. (2013). 'Macroeconomic Variables and the Productivity of the Manufacturing Sector in Nigeria: A Static Analysis Approach.' Journal of Emerging Issues in Economics, Finance and Banking (JEIEFB), 1(5): 362-380.

Ogundipe, A.A, Uzoma, O.A, and Bowale, E.E (2017) "Monetary Policy Shocks and Manufacturing Sector Output in Nigeria: A Strutural Var-Approach" Journal of Internet Banking and Commerce.

Okonkwo,O.N, Godslove, E.K and Mmaduabuchi, E.F (2015). 'Monetary Policy and Manufacturing Sector in Nigeria'. SSRG International Journal of Economics and Management Studies (SSRG-IJEMS), Vol. 2, Issue 1, January-February 2015.

Owolabi, A.U and Adegbite, T.A (2014). 'The impact of monetary policy on industrial growth in Nigeria'. International journal of academic research in business and social sciences, Jan., 2014, Vol. 4, No. 1.

Vizek, M. (2006). 'Econometric Analysis of Monetary Transmission Channels in Croatia' Privrednakretanjaiekonomskapolitika, 109(16): 2861.

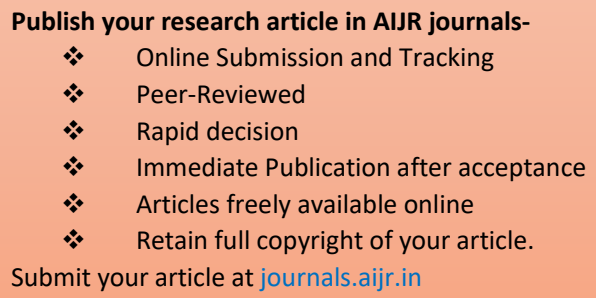

Publish your books with AIJR publisher-

* Publish with ISBN and DOI.

* Publish Thesis/Dissertation as Monograph

* Publish Book Monograph.

* Publish Edited Volume/ Book

* Publish Conference Proceedings

- Retain full copyright of your books.

Submit your manuscript at books.aijr.org 